\title{
Internationalization Modules Of The Higher Education System In Iraq
}

Basil K. Mohamed, Oregon State University, USA

\begin{abstract}
The internationalization of higher education is a natural result of the internationalization of the world's material and intellectual development, which means the modern types of organizations that could maintain worldwide cooperation and competition of commerce, industry and education. The education institutions in developing countries like Iraq are controlled primarily by national authorities, while internationalization could accept education objectives which are not defined by national views, but by international scope of scientific developments and multicultural enhancement.
\end{abstract}

This research reviews the various aspects of the higher education system in Iraq and highlights the internationalization modules that enhance vital connections between Iraqi educational institutions and international organizations.

In order to address the academic viewpoints toward internationalization in Iraq, a field survey was conducted using a questionnaire list. The research sample selected for the survey included high-level professional personnel to identify key problems and how the higher education system practically implemented the internationalization modulus in different activities, such as international curricula, international students, admission standards, international scholarships, collaborative student programs, intercultural communications, languages, textbooks, conferences, and workshops.

The data collected were analyzed and the results were shown diagrammatically. It focuses on the evaluation of the internationalization contents in higher education and in teaching practices. It also discusses the challenges and opportunities to identify the promising teaching practices that could be achieved.

Keywords: Internationalization; Higher Education; System; Developing Countries; Iraq

\section{INTRODUCTION}

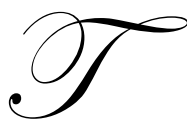

he internationalization of higher education is a natural result of the internationalization of the world's intellectual development and is demanded by the economic development of society. Development and competition require joint efforts to achieve the cultivation of high-level professional personnel and cooperation in scientific research to handle key problems beyond the limits of one's country.

Internationalization is generally defined as increasing cross-border activities amidst persistence of borders, and universities are increasingly required to provide an education that fosters global knowledge, skills, and languages in order to perform professionally and socially in an international and multicultural environment (Mary, 2006).

The internationalization of economic activities calls for that of higher education, in particular, which can be carried out through the internationalization of students, teachers, curriculum and research. Despite its potential economic and political contributions, an overemphasis on the intake of foreign students may have a negative impact on host countries, both culturally and academically (Tai, 2004). 
Internationalism can have significant benefits, but it can also have risks. Countries without well-developed higher education systems, and the citizens of those countries, can have access to higher education of the highest quality, which can help build domestic capacity. However, the risk is that international opportunities are likely to be unevenly distributed at the national and individual levels, militating against poorer, smaller countries and poorer students (Hatakenaka, 2004). The internationalization of higher education is basically the process of presenting exchange activities in education and research of various kinds among universities and institutions in different countries.

Limited access to higher education sustains social inequality in the world. Therefore, the internationalization of higher education can contribute to a more democratic, fair and equal world. Without adequate higher education and research institutions providing a critical mass of skilled and educated people, no country can ensure genuine endogenous and sustainable development (Stier, 2002).

The main aims of internationalization are to (Algirdas, 2006):

1. Promote multicultural and intercultural education

2. Improve learning experiences of exchange students at host institutions

3. Contribute to improving the teaching experiences of teachers who instruct exchange students in mixed groups with home students

4. Improve the level of intercultural competences of all those involved in university education

5. Raise awareness within universities regarding multiculturalism

6. Describe exchange students' specific needs in the classroom

7. Promote continuous staff training for multiculturalism and interculturalism

\section{HIGHER EDUCATION IN IRAQ}

The higher education system in Iraq used to have internationalization content since its establishment, according to the British standards during the first half of the $20^{\text {th. }}$ century. Ultimately, this system applied education standards which were the key dimensions of international knowledge in many scientific branches and also in the administration of the higher education institutions. Hence, there was a serious concern to introduce international issues into the curricula and in many fields.

Modern universities in Iraq were established during the second half of the last century, beginning with the University of Baghdad in 1957, uniting several constituent colleges in the process. During the 1960s, five more universities were established - the University of Technology and the Al-Mustansirya University in Baghdad, as well as universities in Basrah, Mosul, and Sulaymaniah. Further development of higher education in Iraq was characterized by the establishment of technical institutes reflecting the considerable demand for qualified technicians created by the flourishing oil industry. The Ministry of Higher Education and Scientific Research (MHESR) is responsible for all post-secondary education, including technical education and research centers in Iraq, and the current higher education system comprises 24 universities and 72 technical institutes under the management of the MHESR. This includes 200 colleges, 800 departments, and 28 research centers (Ali, 2006).

Nationwide, there are 350,000 undergraduate students, 15,000 postgraduate students, and nearly 30,000 teaching faculty. The major fields of study offered by the universities are education, arts, law, social sciences, administration, economics, natural sciences, engineering and technology, medical sciences, veterinary medicine and agriculture (UNESCO, 2004).

Of the approximately 25,000 academic university teaching staff, $55 \%$ are male and $45 \%$ female, and $43 \%$ of the teaching force is concentrated in Baghdad. The average staff/student teaching ratio is 1:13 being much more favorable than neighboring countries, such as Jordan (1:30) and Saudi Arabia (1:20). In Iraq, the minimum educational qualification for a teaching post in higher education is a master's degree. However, one third of the teaching staff lacks a master's degree; $28 \%$ of the staff has doctorates, $39 \%$ masters and $33 \%$ bachelor's degrees (UNESCO, 2005). 
In Iraq and after the 1970s, the higher education trend has taken the form of university nationalism. The academic environment was urged to secure the country by means of learning and rapid development was noticed under the governmental control. Because of government investment, the Iraqi education system experienced dramatic quantitative growth immediately before sanctions were imposed. During the economical embargo imposed on Iraq due to United Nation Security Council resolutions after 1990, the higher education system was influenced significantly and its performance noticeably declined. After the war in 2003, the higher education system witnessed new deteriorating conditions due to many factors summarized as follows (Agusti, 2005):

1. Many universities were destroyed and their infrastructures and buildings were burned.

2. Most higher education professionals excluded, dismissed, expelled, killed or left Iraq due to threats by different extremist groups.

3. New political parties in the new regime, especially the religious parties, have a noticeable interference in the academic life and many students have been involved in political practices that disturbed the university environment.

\section{FIELD SURVEY}

The field survey was conducted by participation of many Iraqi universities selected from the Ministry of Higher Education to reflect the internationalization modules throughout higher education activities. In order to understand the reality of the internationalization requirements, and to describe the application of its modules throughout the teaching process, a questionnaire list (see Appendix) was used for this purpose. It was prepared according to the internationalization survey standards applied in most international universities (Brad, 2011).

This methodology was employed effectively for gathering information representing the reality of internationalization modules currently applied throughout various teaching activities and other educational aspects. The respondents for the questionnaire list where identified by choosing a simple answer (always, almost, sometimes, rarely, no) representing a scale from 1 (very low or "no") to 5 (very high or "always") to highlight the extent to which internationalization modules have been applied in Iraqi universities.

The research sample was selected from personnel who have much experience in the higher education field in Iraq. Therefore, 72 questionnaire lists were distributed to a number of deans, department chairs, professors and lecturers in the selected higher education institutions. Fifty lists were collected with complete answers, as shown in Table 1, and the research sample profile is shown in Figure 1.

Table 1: Questionnaire Lists Distribution

\begin{tabular}{|l|c|c|}
\hline \multicolumn{1}{|c|}{ Institutions } & Questionnaire Lists Distributed & Questionnaire Lists Collected \\
\hline Baghdad university & 8 & 6 \\
\hline Al-Nahreen university & 8 & 6 \\
\hline Al-Mustansiriyah university & 8 & 6 \\
\hline University of technology & 8 & 5 \\
\hline Al-Basrah university & 8 & 5 \\
\hline Al-Mosul university & 8 & 4 \\
\hline Tikret university, & 6 & 4 \\
\hline Al-Anbar university & 6 & 4 \\
\hline Babylon university & 6 & 4 \\
\hline Al-Kufa university & 6 & $\mathbf{5 0}$ \\
\hline Total & $\mathbf{7 2}$ & \\
\hline
\end{tabular}




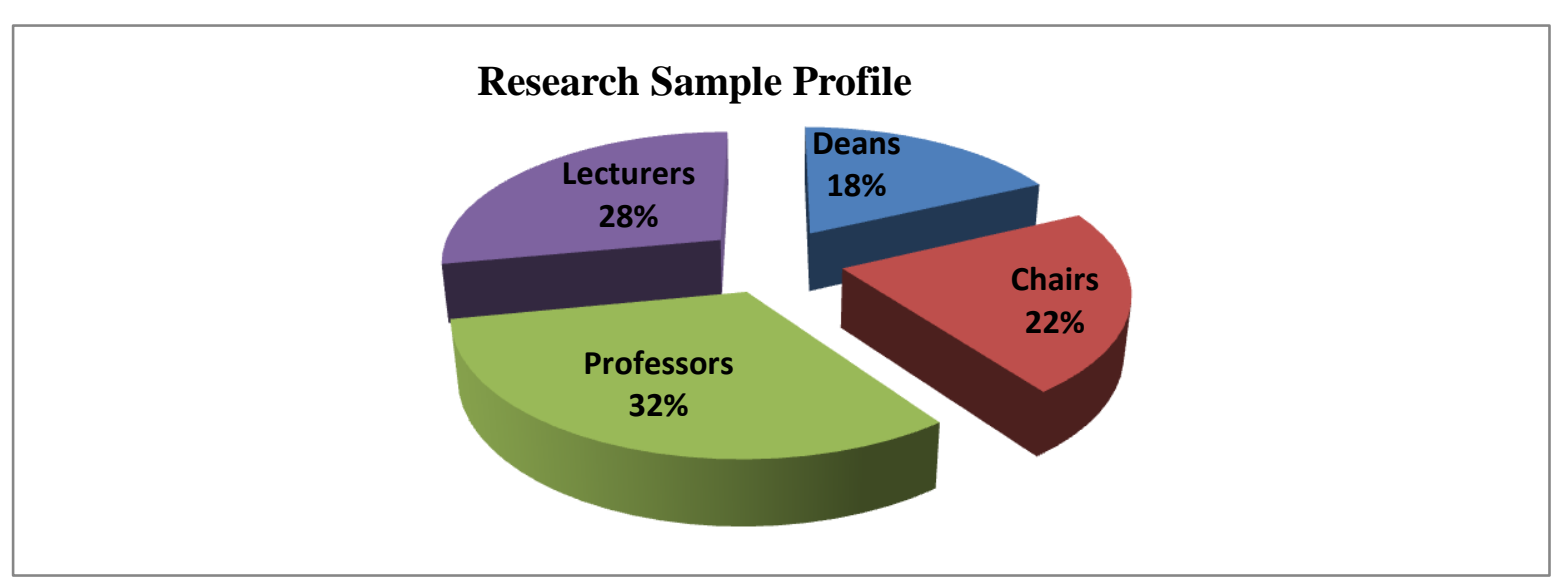

Figure 1: Research Sample Profile

\section{RESULTS AND DISCUSSION}

The results collected, according to the survey axes in the questionnaire list, were analyzed and shown in histograms as follows:

\section{International Standards}

Iraqi higher education achieved a high performance level until the 1970s. It then witnessed a significant declination during the 1980s and 1990s when the university nationalization policy was applied and the international modules were negatively influenced. Figure 2 shows that $30 \%$ of the research sample answered that international standards (always) applied, while 28\% answered (almost) and 22\% (sometimes), yet only $12 \%$ of the sample answered (rarely) and 8\% (no). These results, which were gathered in 2011, indicate that the political impact has significantly decreased over the years and Iraqi universities restored its education standards.

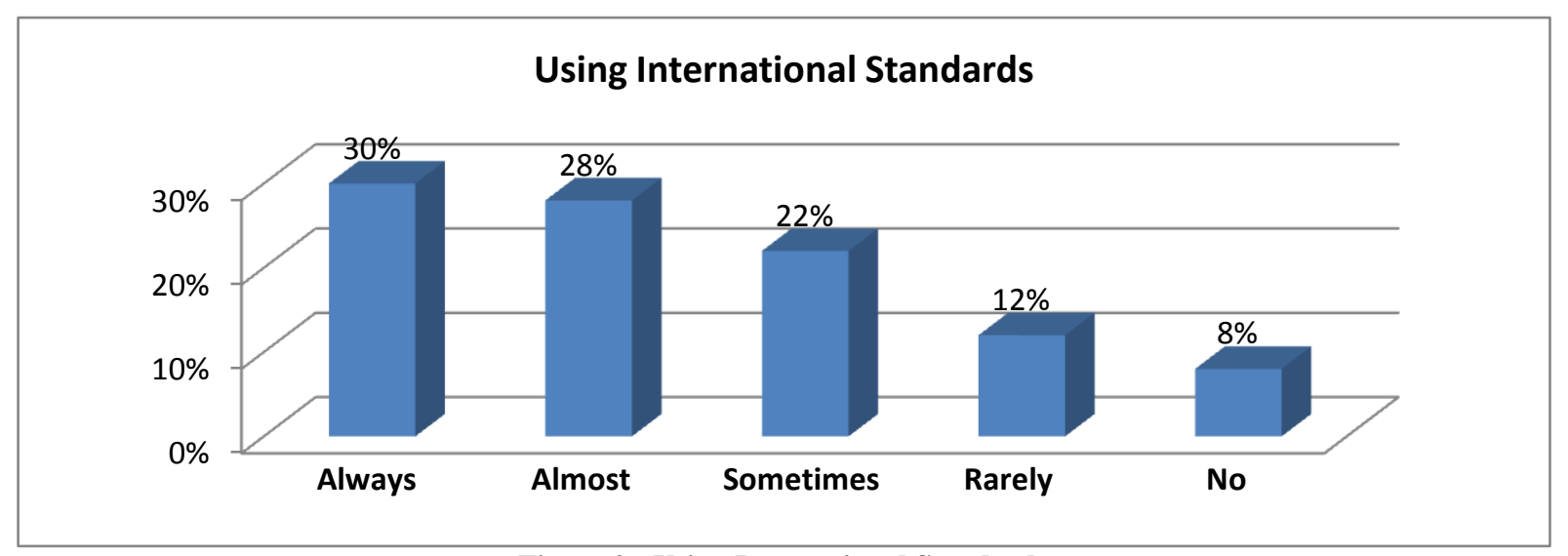

Figure 2: Using International Standards

\section{Curriculum Internationalization}

The results in Figure 3 show that 30\% of the respondents reveal that Iraqi educational curriculum has (always) international dimension while other percentages did not show the same trend for this dimension, where $20 \%$ of the sample answered (rarely) and $12 \%$ (no). 
The research sample commented that the internationalization concept is not widely understood as an educational attitude, while the curriculum was not updated since the war in 2003 and there is neither an international accreditation system nor a national one applied in higher education institutions.

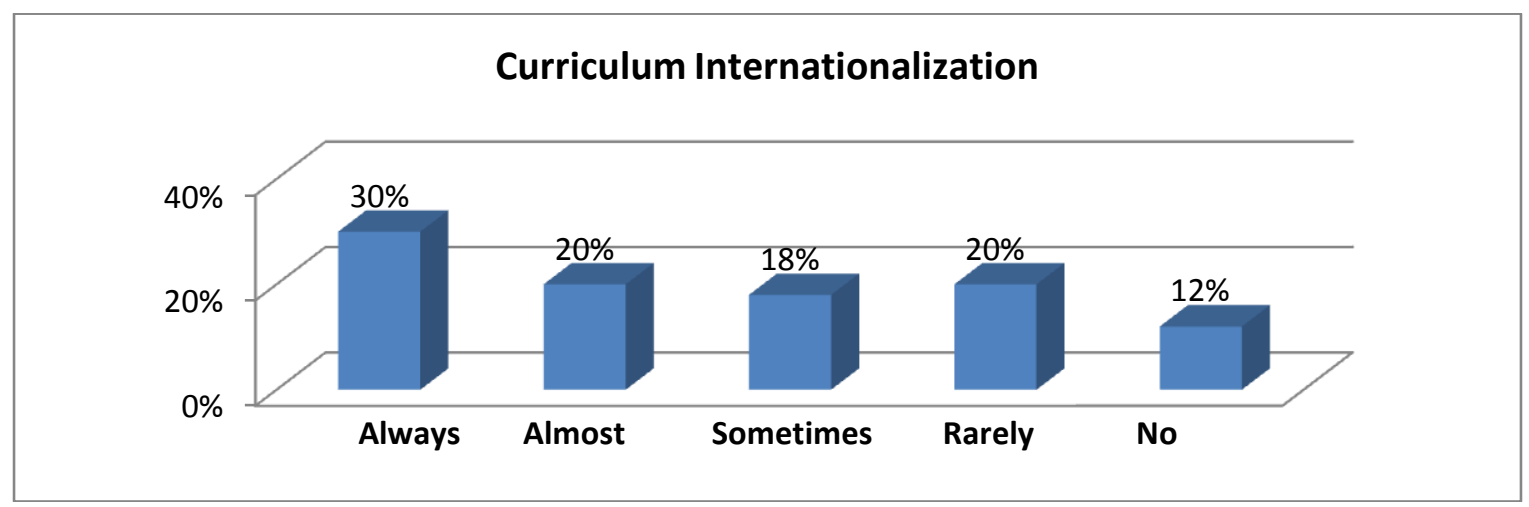

Figure 3: Curriculum Internationalization

\section{International Textbooks}

Many courses used to have certain textbooks for teaching various subjects, including medical, engineering, physics, social, arts, history sciences, etc. These international textbooks are mostly in English. Figure 4 indicates that $40 \%$ of the respondents (always) use international textbooks in medical and engineering colleges; $24 \%$ show that these textbooks are also used in the college of sciences; and other percentages reveal that social sciences in Iraq have never used international textbooks.

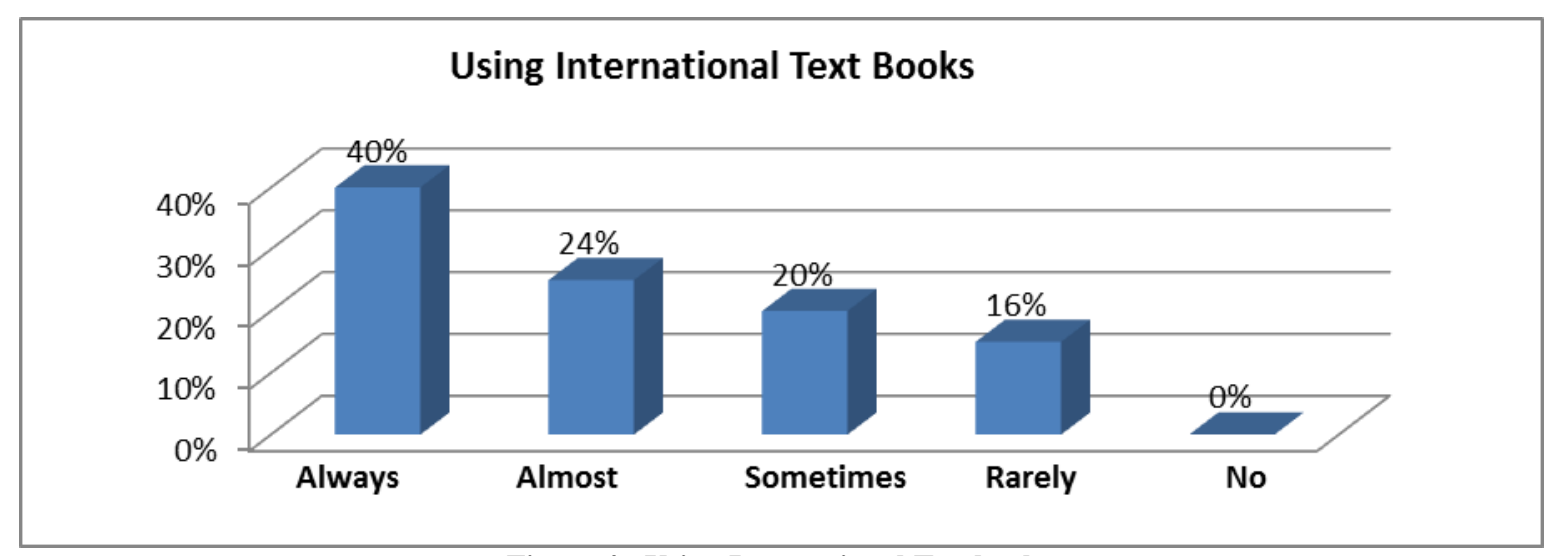

Figure 4: Using International Textbooks

\section{Communication with International Organizations}

Figure 5 shows a weak trend in communication with international organizations and the highest percentages are $32 \%$ (rarely) and 26\% (no). Sample comments indicate that Iraqi universities have limited relations with international organizations through signed agreements because of the political influence. Meanwhile, some universities formed good connections with international universities for the benefit of post-graduate researches. 


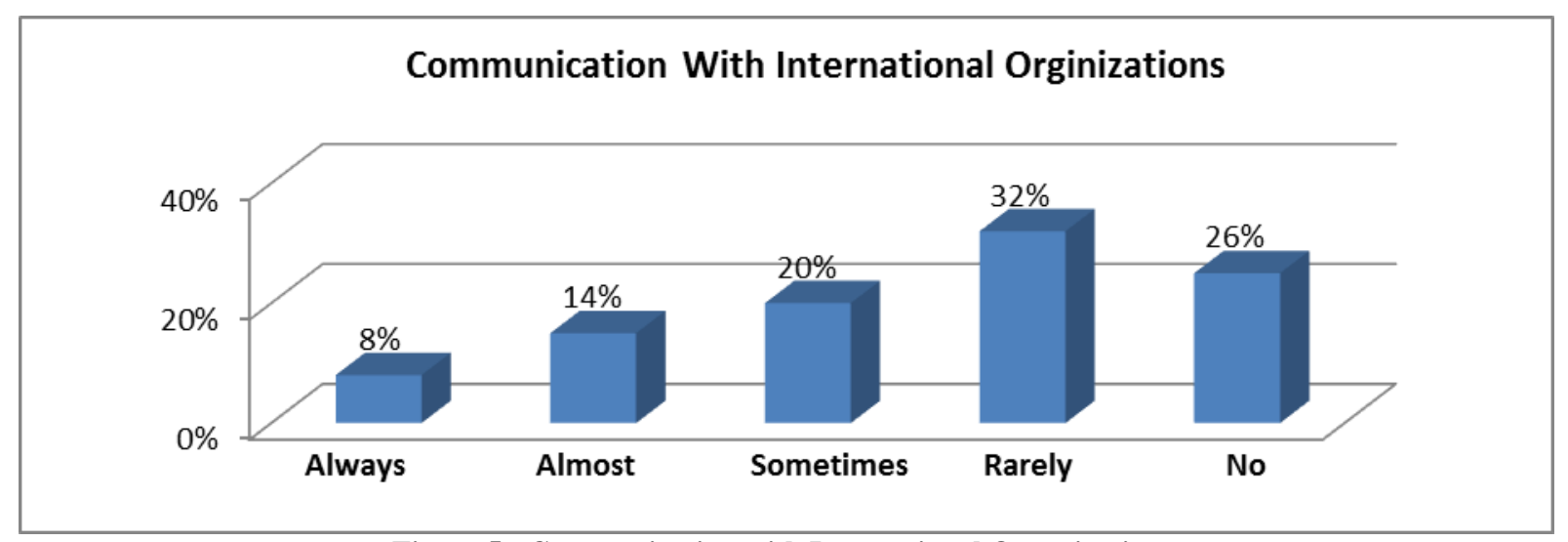

Figure 5: Communication with International Organizations

\section{Assignments Including International Contents}

The results in Figure 6 show that 30\% of the higher education instructors (sometimes) use assignments, including international content. The results also show an approximate normal distribution of the results with an average in the middle and two extreme ends, which represents a normal attitude toward international dimension. The research sample comments indicate that giving such assignment depends upon the curriculum and teacher experience.

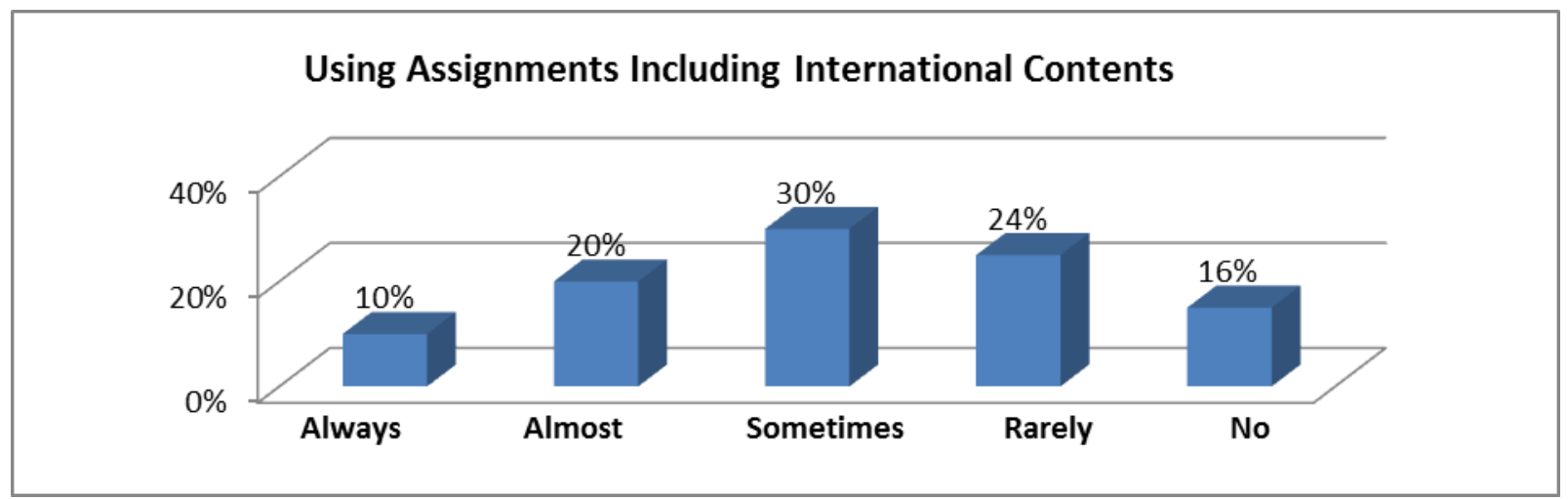

Figure 6: Using Assignments Including International Contents

\section{Using International Languages}

The results in Figure 7 indicate that higher percentages of the research sample respondents (34\%) show (always) and 28\% (almost). However, the English language is used widely in medical and engineering education, while the national language is currently used in other social sciences. The sample comments indicate that most of the translated textbooks did not satisfy the scientific standards requirements during the last three decades. 


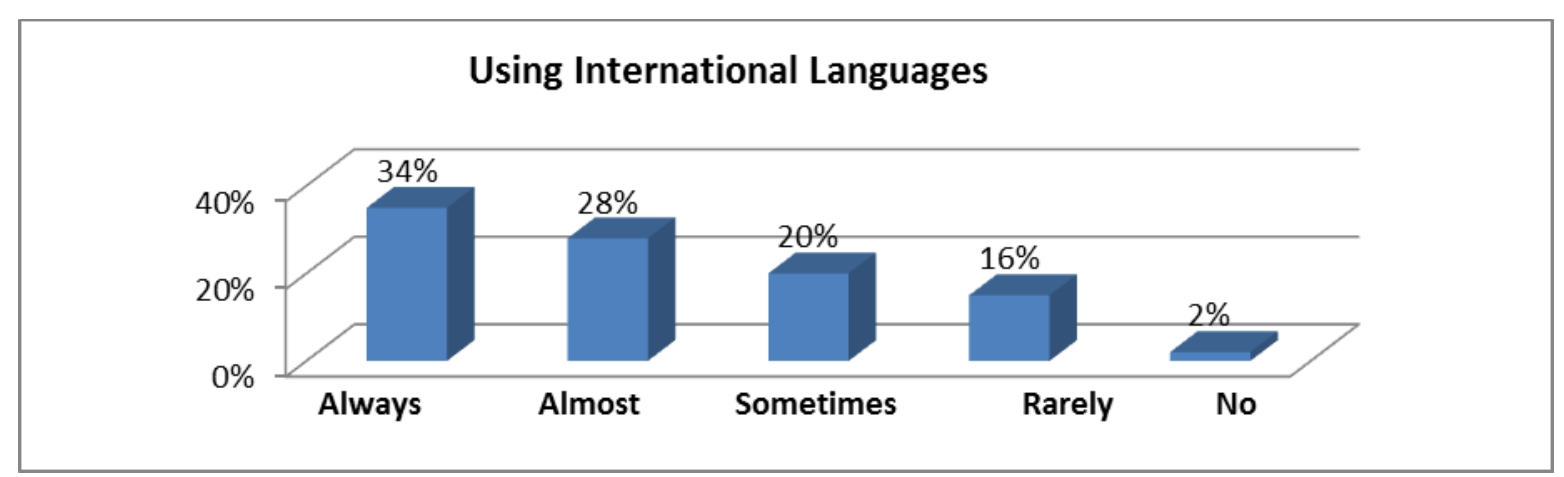

Figure 7: Using International Languages

\section{Internships Study Abroad}

Figure 8 shows that the highest percentages were 35\% (no) and 24\% (rarely) and the other percentages were $20 \%$ (sometimes), 10\% (almost), and $8 \%$ (always). Clearly, the results show a negative trend for study abroad, but the sample comments indicate that a new educational dimension, which seeks internships to study abroad for some universities, was recently noticed to encourage graduate students to be involved in such programs.

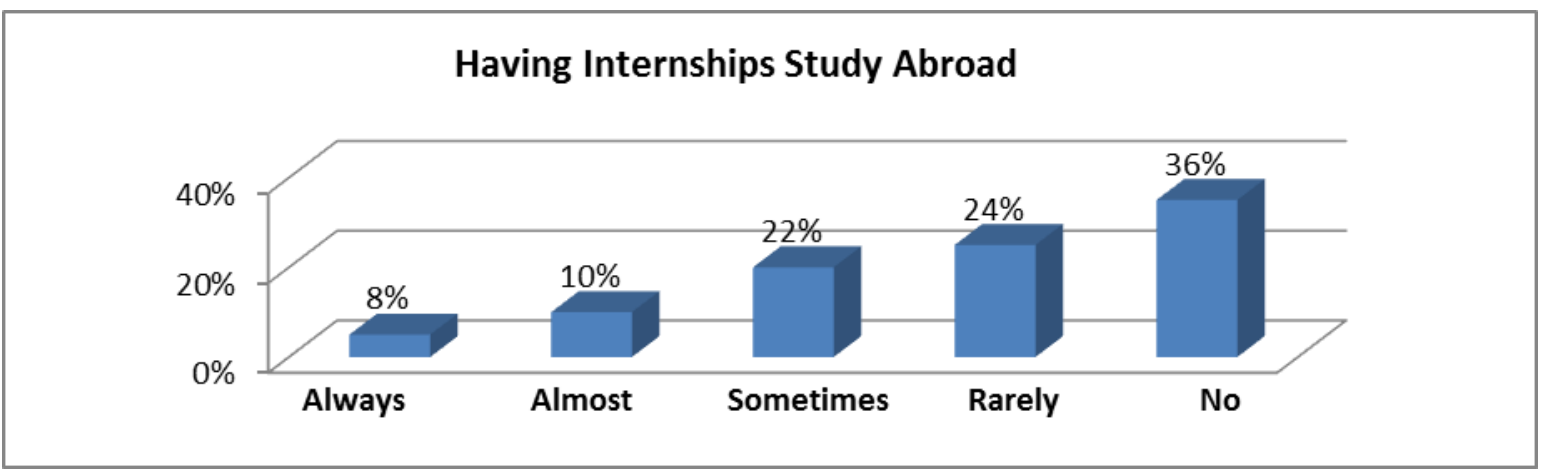

Figure 8: Having Internships Study Abroad

\section{International Scholarship Exchange Programs}

Figure 9 shows that a higher percentage of the sample (40\%) answered "no". The research sample comments indicate that so far there is not an international scholarship exchange program being used in the ministry of Higher Education and Scientific Research in Iraq and to have such a program would require that a new international policy be adopted by the ministry.

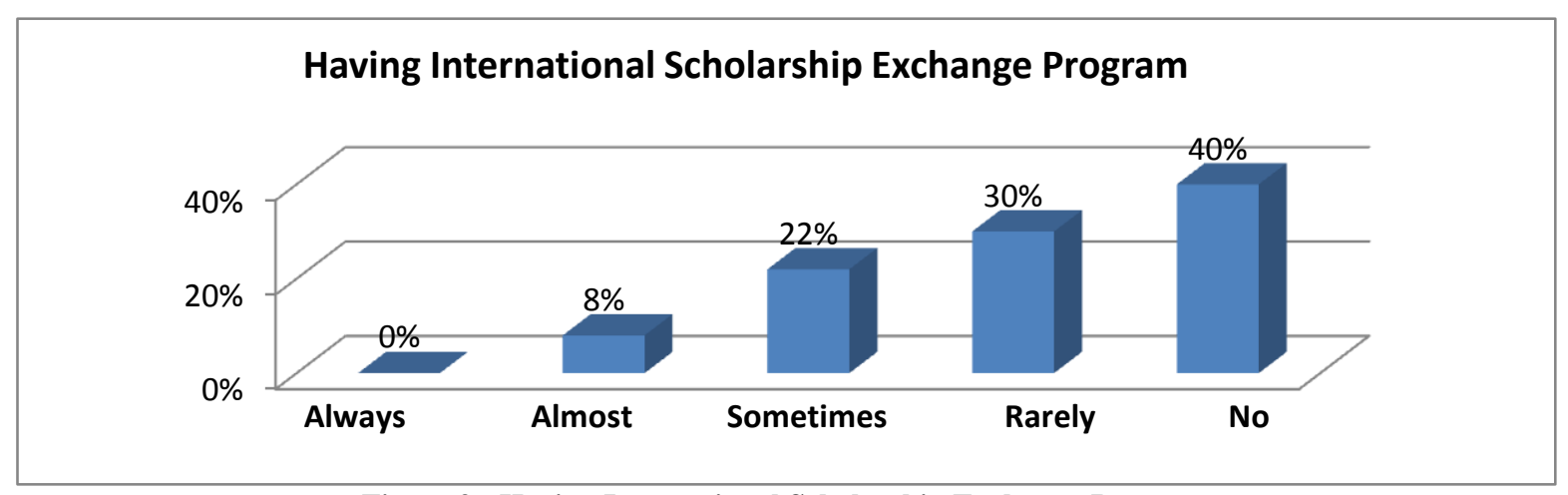

Figure 9: Having International Scholarship Exchange Program 


\section{Collaborative Graduate Program}

As indicated above, the research sample respondents revealed that the Ministry of Higher Education and Scientific Research attempts to set out several scientific agreements with international universities, including collaborative graduate programs. Figure 10 clearly shows the same trend as Figure 9.

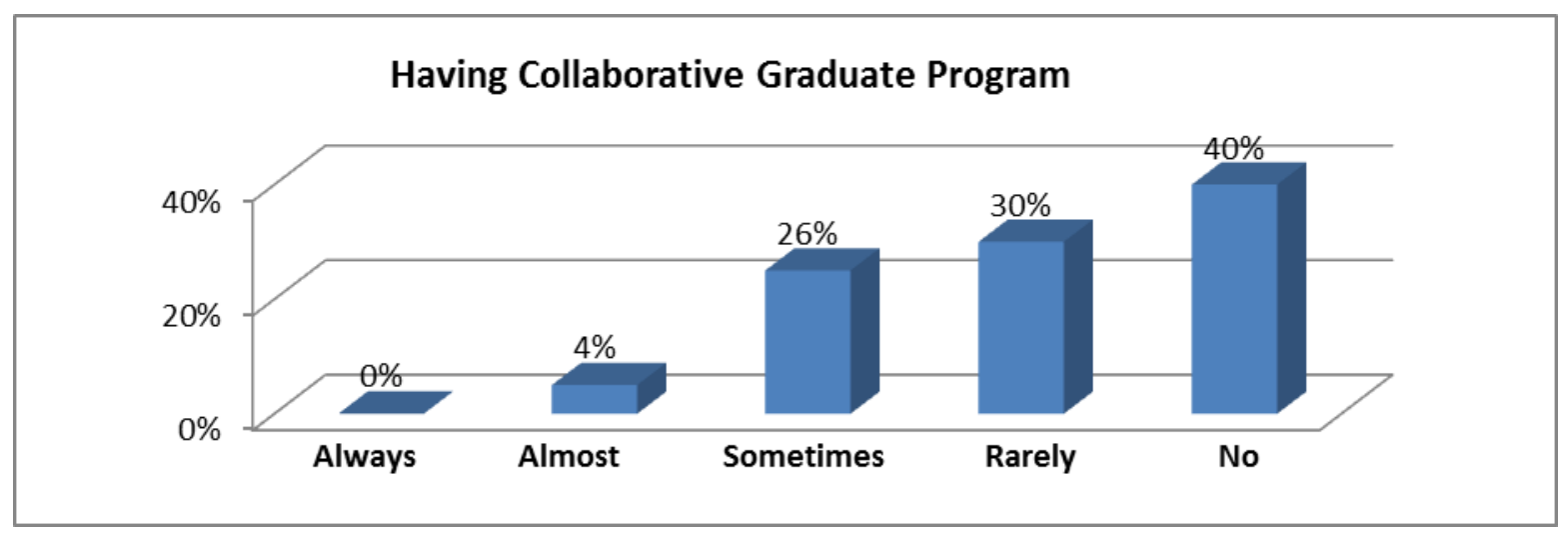

Figure 10: Having Collaborative Graduate Program

\section{Joint Conferences and Workshops}

Figure 11 shows that the higher percentages (36\% for no and $30 \%$ for rarely) indicate a very weak participation in joint conferences and workshops abroad. Meanwhile, the sample comments indicate that sometimes this participation is limited for those in high positions in the administration sector. Generally, there is neither scheduling for such participations nor conference announcements.

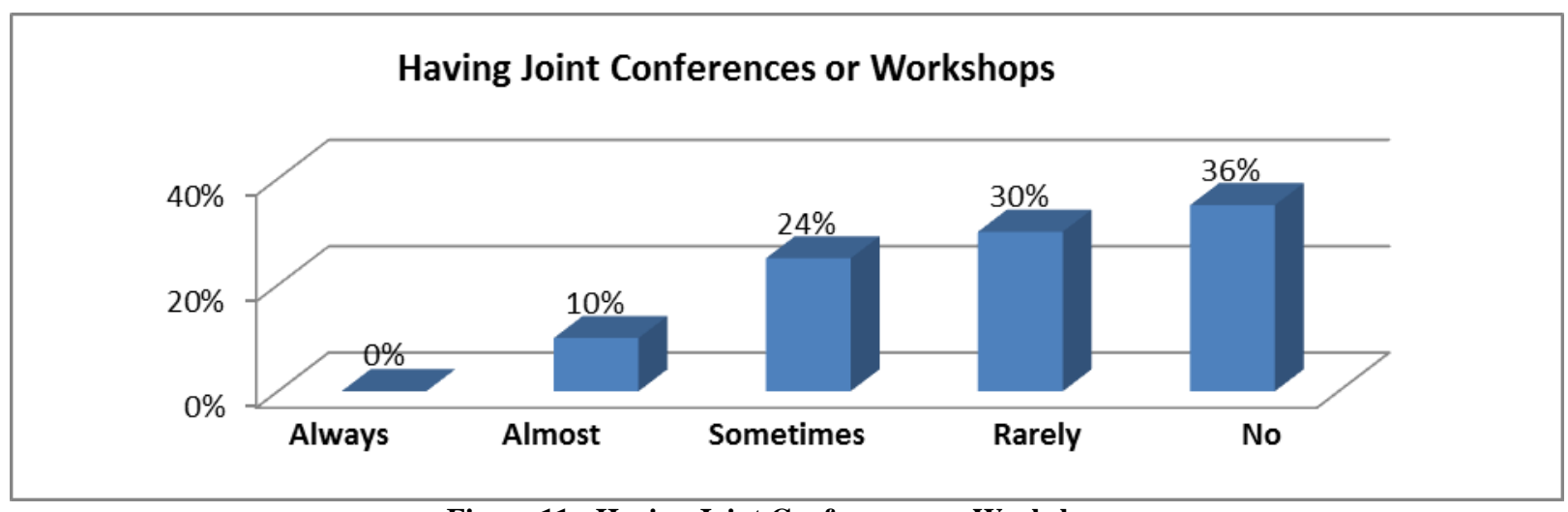

Figure 11: Having Joint Conferences or Workshops

\section{CONCLUSIONS}

1. Results show that Iraqi current culture, within the higher education system, recognizes and agrees with international dimensions.

2. Vitalization of international communication and the exchange programs are highly needed to improve international standards for the higher education system.

3. Exchange and accreditation of programs, courses and degrees, including the sharing of curriculums, are needed to develop suitable systems adopted by the universities. 
4. The political system in Iraq needs to promote democratic values, especially in the higher education system, and to maintain the independence preventing political interference.

5. Universities should encourage and facilitate across-the-border activities for students and faculty to have an international experience.

6. The Ministry of Higher Education and Scientific Research should offer international programs for the universities, such as a scholarship exchange program, collaborative graduate program, internship study abroad program, etc.

\section{AUTHOR INFORMATION}

Basil K. Mohamed is a Visiting Professor in the School of Civil and Construction Engineering / Oregon State University. Research interest: Sustainability and Construction Management, Quality Assurance Systems and Global Engineering Education. E-mail: mohamed@engr.oregonstate.edu

\section{REFERENCES}

1. Agusti V. De Santisteba, (2005),"Sanctions, War, Occupation and the De-Development of Education in Iraq", International Review of Education Vol. 51 No 1. Madrid, Spain.

2. Algirdas V. Valiulis, Donatas Valiuli, (2006), ’The Internationalization of Higher Education: a Challenge for Universities", Global J. of Engng. Educ., Vol.10, No.2, Published in Australia.

3. Ali Latif, (2006),'Democratization and Radicalization in Iraqi Campuses”, Iraqi Prospect Organization IPO, www.iprospect.org.uk/radicalization.

4. Brad Piazza, Gary Plato, \& Alexandra Sielaff, (2011), "Curriculum Mapping of International Education Content at Waukesha County Technical College" Summer Institute, Madison, WI.

5. Hatakenaka, S. (2004), Internationalism in Higher Education: A Review. Higher Education Policy Institute", from website: http://www.hepi.ac.uk/

6. Mary M. Kritz (2006),"Globalization and internationalization of Tertiary Education", Final Report submitted to the United Nations Population Division by Population and Development Program and Polson Institute for Global Development Cornell University Ithaca, New York.

7. Stier, J., "Internationalization in Higher Education: Unexplored Possibilities and Unavoidable Challenges", Paper Presented at the European Conf. on Educational Research, Lisbon, Portugal (2002), from website http://www.leeds.ac.uk/educol/

8. Tai, H-H., (2004), 'The internationalization of higher education: a Comparative Study of Asian- Pacific Countries, Foreign Student Policies', Bulletin of Educational Research, 50, 2, pp.53-84.

9. UNESCO, (2004), "Iraq: Education in transition, Needs and Challenges." Paris.

10. UNESCO Regional office for education in the Arab states (UNDBAS) (2005), "Situational Analysis of General Education in Iraq, Needs \& Proposed Areas for Assistance. Mission Report, Beirut, Lebanon. 


\section{APPENDIX}

\begin{tabular}{|c|c|c|c|c|c|c|}
\hline \multicolumn{7}{|c|}{ Questionnaire List } \\
\hline \multicolumn{7}{|c|}{ Evaluation of Internationalization Contents of Higher Education in Iraq } \\
\hline No. & General Characteristics & Always & Almost & Sometimes & Rarely & No \\
\hline $1-$ & Do you think curriculum ought to be internationalized? & & & & & \\
\hline $2-$ & $\begin{array}{l}\text { Do you use assignments that include an international } \\
\text { component? }\end{array}$ & & & & & \\
\hline $3-$ & Do you use international textbooks? & & & & & \\
\hline $4-$ & $\begin{array}{l}\text { Do you include any international standards throughout } \\
\text { courses? }\end{array}$ & & & & & \\
\hline $5-$ & Do you have any internships for study abroad? & & & & & \\
\hline 6- & Do you have international scholar exchange program? & & & & & \\
\hline $7-$ & Do you have collaborative graduate program? & & & & & \\
\hline $8-$ & $\begin{array}{l}\text { Do you use international language beside your national } \\
\text { one? }\end{array}$ & & & & & \\
\hline 9- & $\begin{array}{l}\text { Do you conduct intercultural communication with } \\
\text { international organizations? }\end{array}$ & & & & & \\
\hline $10-$ & $\begin{array}{l}\text { Do you have joint conferences or seminars or } \\
\text { workshops with international institutions? }\end{array}$ & & & & & \\
\hline
\end{tabular}

Please make your comments on a separate paper and

1. Write your personal definition for the internationalization in education.

2. Add any specific remarks about the questionnaire list. 